\title{
UJI COBA PROSES KOAGULASI-FLOKULASI AIR BAKU UNTUK PDAM DANAU TELOKO DAN TELUK GELAM DI KAYU AGUNG KABUPATEN OKI PROPINSI SUMATERA SELATAN
}

\author{
Petrus Nugro Rahardjo \\ Pusat Teknologi Lingkungan, BPPTeknologi \\ JI. MH. Thamrin No. 8 Jakarta Pusat
}

\begin{abstract}
Regional Drinking Water Company (PDAM) of County Ogan Komering llir has two problematic water treatment units. The first is located in Danau Teloko and the other is in the Teluk Gelam. The main problem is that many organic pollutants (namely peat water) contained in raw water. Therefore, PDAM can not be optimal to supply all the needs of drinking water for the community. PDAM have tried to treat the raw water of peat with the process of flocculation and coagulation, but the results did not meet quality standards as drinking water. This research is a trial test to obtain the optimum condition for flocculation and coagulation processes in water treatment. The results were very succesful and get the optimum pH is about 7.5 and a chemical dose of 80 ppm Aluminum Sulphate as the coagulant. Turbidity of water produced is 4 NTU and visually looks very clean. Better to add a synthetic polymer (PAC) as an additive to the process of flocculation and coagulation. Based on calculations, PDAM Danau Teloko will require the amount of coagulant (Aluminum Sulphate) $138.24 \mathrm{~kg}$ per day to produce 40 liters of drinking water per second.
\end{abstract}

\section{Keywords : Raw Water, Flocculation, Coagulation, Water Treatment Plant}

\section{PENDAHULUAN}

\subsection{Latar Belakang}

Instalasi Pengolahan Air (IPA) di kawasan Danau Teloko yang dikelola oleh Perusahaan Daerah Air Minum (PDAM) Kabupaten Ogan Komering llir dibangun pada tahun 2006. IPA ini dirancang berkapasitas 40 liter air minum per detik (1). Lokasi IPA ini terletak di dalam kawasan perkebunan kelapa sawit dan di tepi Danau Teloko yang berupa rawa-rawa yang sangat luas (> $50 \mathrm{Ha}$ ). Diperkirakan kedalaman maksimum kawasan rawa atau danau ini lebih dari 10 meter. Dengan demikian secara kuantitas, Danau Teloko ini mempunyai potensi sebagai sumber air yang sangat baik. Namun secara kualitas, karena danau ini terbentuk dari suatu daerah gambut, maka air danau mengandung pengotor organik yang membuat warna air menjadi kuning kecoklatan (seperti warna air teh). Derajat keasaman air danau ini sangat rendah, yaitu $\mathrm{pH}=4,0$ (2). Pada saat musim hujan, karena dipengaruhi oleh banyaknya curah hujan yang turun, maka warna air sedikit lebih muda sebagai akibat dari proses pengenceran oleh air hujan. Namun pada musim kemarau air kawasan rawa ini kembali semakin berwarna coklat.

IPA Danau Teloko menggunakan air danau ini sebagai sumber air bakunya. Jadi sistem in-take ditempatkan di bagian yang agak menjorok ke tengah danau yang mempunyai kedalaman air yang cukup dan tidak akan kering sekali pun musim kemarau panjang (lihat Gambar 1). Namun karena adanya pengotor warna gambut tersebut dan proses pengolahan yang sama sekali tidak sempurna, maka hasil pengolahan IPA belum menunjukkan hasil yang baik, yaitu air masih berwarna kuning dan agak keruh. Karena itu air produksi PDAM Danau Teloko belum dapat menjadi andalan daerah dalam memenuhi kebutuhan air bersih masyarakat sekitarnya.

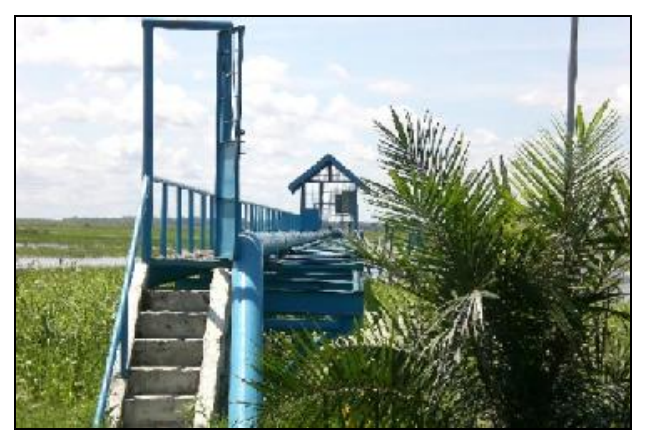

Gambar 1. Sistem Intake PDAM Danau Teloko

Demikian pula halnya dengan IPA PDAM di Teluk Gelam yang juga mempunyai masalah sama seperti IPA Danau Teloko, hanya secara kualitas, air bakunya masih lebih baik dari pada air rawa di Danau Teloko. Pengotor warna organik gambut di Teluk Gelam tidak sepekat seperti air rawa Danau Teloko (3). Untuk mengatasi masalah di kedua IPA PDAM di 
Kabupaten OKI ini sangat dibutuhkan suatu rangkaian uji coba proses Flokulasi-Koagulasi, sehingga diperoleh suatu kondisi proses yang optimal.

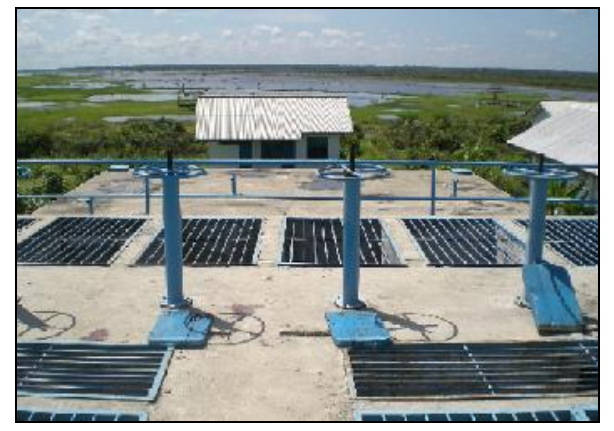

Gambar 2. Unit Flokulasi-Koagulasi dan Unit Pengendap PDAM Danau Teloko

\subsection{Tujuan}

Sesuai dengan permasalahan yang telah diuraikan di atas, maka kegiatan ini bertujuan untuk melakukan uji coba proses flokulasikoagulasi terhadap kedua sumber air baku dan selanjutnya menentukan kondisi proses optimal dengan berdasar pada kondisi keasaman dan jumlah pembubuhan bahan koagulan. Khusus untuk IPA Danau Teloko target tujuan sampai pada perhitungan kebutuhan bahan koagulan (Tawas) dan bahan pendukung lainnya.

\subsection{Metodologi}

Metode yang digunakan dalam langkah uji coba proses Flokulasi-Koagulasi ini adalah:

- Survey langsung ke lokasi Danau Teloko dan Teluk Gelam.

- Pengambilan contoh air baku di kedua lokasi sumber air tersebut.

- Pengukuran derajat kekeruhan dengan alat Spectronic 20.

- Ujicoba optimalisasi proses FlokulasiKoagulasi dengan alat Jar Test.

- Pengamatan visual selama proses pengendapan.

\section{TAHAP PERSIAPAN}

\subsection{Peralatan}

Dalam uji coba proses flokulasi dan koagulasi dibutuhkan suatu alat khusus, yaitu Jar Test. Alat ini terdiri dari suatu rangkaian sistem, yaitu empat gelas kimia yang berukuran masingmasing $500 \mathrm{ml}$ dan masing-masing gelas dilengkapi dengan satu pengaduk propeler (stirrer). Keempat gelas ini nantinya diisi dengan air baku yang akan diuji-coba.

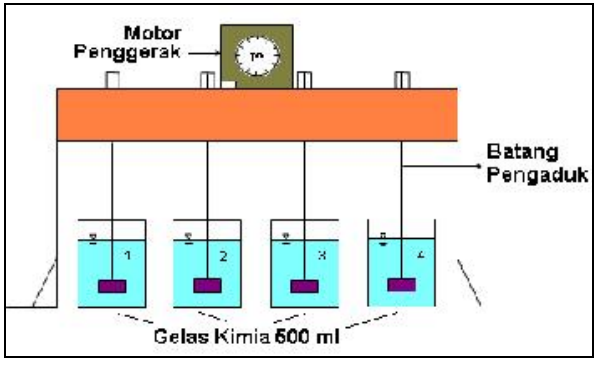

Gambar 3. Konfigurasi Peralatan Jar Test

\subsection{Larutan Basa}

Larutan basa berfungsi untuk mengatur derajat keasaman air baku dalam proses penggumpalan. Diketahui bahwa air baku yang berupa air gambut mempunyai derajat keasaman yang sangat rendah, yaitu $\mathrm{pH}= \pm 4$. Larutan basa yang digunakan dapat bermacam-macam, namun dalam uji coba kali ini digunakan kapur atau $\mathrm{CaO}$. Oksida Kalsium ini dalam air akan bereaksi dengan air menjadi senyawa basa $\mathrm{Ca}(\mathrm{OH})_{2}$.

$\mathrm{CaO}+\mathrm{H}_{2} \mathrm{O} \leftrightarrow \mathrm{Ca}(\mathrm{OH})_{2}$

Pada uji coba ini larutan kapur yang dipersiapkan adalah berkadar $20 \%$. Pembuatan larutan basa $20 \%$ dilakukan dengan melarutkan kapur sebanyak 200 gram ke dalam 1 liter air bersih. Larutan senyawa ini yang dapat digunakan untuk menetralkan derajat keasaman menjadi sekitar 7 (tujuh) atau bahkan lebih agar sesuai dengan kondisi yang diinginkan untuk proses penggumpalan.

\subsection{Larutan Tawas}

Larutan Tawas berfungsi untuk menggumpalkan pengotor organik yang terdapat dalam air baku yang bergambut. Seperti juga penyiapan larutan basa, larutan Tawas juga dibuat dengan konsentrasi yang sama, yaitu $20 \%$. Pembuatan larutan Tawas dilakukan dengan melarutkan 200 gram bubuk Tawas ke dalam 1 liter air bersih.

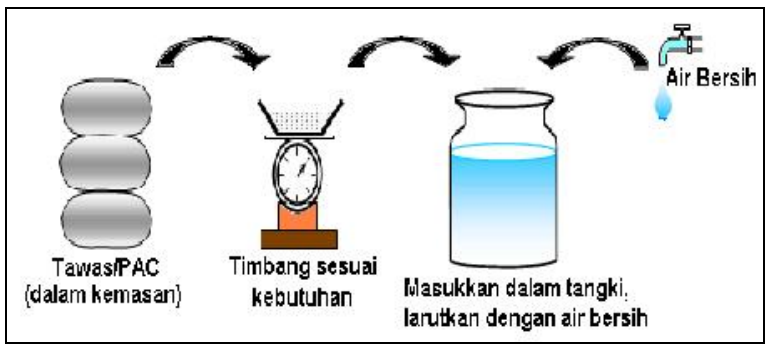

Gambar 4. Cara Pembuatan Larutan Koagulan (Tawas/Alum atau PAC) 


\subsection{Larutan Aditif}

Bahan aditif dimaksudkan untuk meningkatkan kecepatan proses penggumpalan dan atau membuat gumpalan yang terbentuk menjadi lebih berat, sehingga lebih mudah mengendap dalam proses selanjutnya, yaitu sedimentasi. Aditif sebenarnya dapat juga berupa bahan penggumpal, namun penggunaannya lebih spesifik, misalnya digunakan khusus untuk menggumpalkan pengotor organik atau anorganik. Berbagai macam bahan aditif yang tersedia di pasar, misalnya Sirroflok. Pada percobaan ini vahan aditif yang digunakan adalah PAC. Seperti juga bahan-bahan kimia lain yang dipergunakan, pembuatan larutan aditif juga sama, yaitu 200 gram bubuk PAC dalam 1 liter air bersih.

\section{HASIL UJI COBA PROSES KOAGULASI}

\subsection{Kondisi Keasaman (pH)}

Sebenarnya pengaturan $\mathrm{pH}$ untuk proses koagulasi didasarkan pada jenis koagulan yang digunakan. Sebagai contoh, yaitu koagulan Aluminium Sulfat paling efektif pada jelajah $5<\mathrm{pH}<7,5$, koagulan Ferry Khlorida paling efektif pada $\mathrm{pH}$ rendah sampai 4,5 dan Ferro Sulfat paling efektif pada $\mathrm{pH}$ di atas 9,5 (4). Karena Tawas (Aluminium Sulfat) yang digunakan oleh PDAM atau Dinas PU di Kayu Agung sebagai bahan penggumpal, maka pengaturan derajat keasaman harus berada pada suasana $5<\mathrm{pH}<7,5$. Berdasarkan studi literatur diketahui bahwa kondisi optimal untuk proses penggumpalan dengan koagulan Tawas adalah pada $\mathrm{pH} 6,5$ sampai 7,5 .

Dalam penggunaan alat Jar Test, ke dalam keempat gelas kimia (gelas Beaker) yang masing-masing berisi air baku sebanyak 1.000 $\mathrm{ml}$, dibubuhkan tetes demi tetes larutan basa, larutan kapur $(20 \% \mathrm{CaO})$, sehingga diperoleh $\mathrm{pH}$ berturut-turut sebesar $6,6,5,7,0$ dan 7,5. Pengukuran $\mathrm{pH}$ dilakukan dengan menggunakan kertas lakmus. Pada saat pembubuhan larutan basa, air baku dalam gelas beaker harus terus diaduk supaya diperoleh homogenitas yang sempurna. Sebelumnya terlebih dahulu diukur kekeruhan larutan air baku. Dengan alat Portable Spectronic 20, diketahui bahwa kekeruhannya sekitar 37 NTU.

\subsection{Pembubuhan Koagulan (Tawas) dan Pencampuran}

Pembubuhan larutan Tawas ke dalam masing-masing gelas dilakukan dengan meneteskan larutan Tawas (20\%) sebanyak 20 ml. Setelah pembubuhan larutan Tawas (dapat pula dengan penambahan variasi larutan aditif dalam jumlah kecil, yaitu 1-2 ml), kemudian dilakukan pengadukan cepat (>100 rpm) dalam waktu 1 - 2 menit, sehingga air dalam gelas beaker sudah tercampur atau bahan kimia telah terdispersi seluruhnya dan mencapai kondisi yang sempurna (homogen).

\subsection{Proses Koagulasi/Flokulasi}

Setelah pengadukan cepat, segera dilakukan pengadukan lambat (kecepatan pengadukan sekitar 10-20 rpm). Kemudian proses penggumpalan mulai berlangsung. Pada periode ini pengadukan lambat terus dilakukan selama 15 sampai 20 menit untuk membantu terbentuknya flok. Pada proses ini akan terlihat mulai terbentuknya gumpalan-gumpalan yang melayang dalam larutan di masing-masing gelas beaker. Banyak sedikit serta cepat lambatnya penggumpalan pada periode ini harus diamati dengan seksama. Setelah pengadukan lambat dan proses penggumpalan selesai, maka beri kesempatan larutan untuk mengendap secara alami selama kurang lebih 30 menit. Setelah itu lakukan pengamatan akhir dan ukur kembali derajad kekeruhan dari masing-masing gelas Beaker tersebut. Berdasarkan pengamatan ini, kemudian hasil penggumpalan dari masingmasing gelas dibandingkan.

Hasil uji coba dan pengamatan adalah sebagai berikut :

a. Pada kondisi pH 6,0 proses penggumpalan yang terjadi sangat lambat dan ukurannya agak kecil. Satu menit setelah terjadinya proses pencampuran, gumpalan-gumpalan sangat kecil mulai terbentuk dan melayanglayang di dalam air baku yang sedang diproses. Namun gumpalan yang terjadi tetap saja berukuran sangat kecil dan setelah lebih dari 3 menit ternyata partikelpartikel flok yang terbentuk agak sulit untuk membentuk flok yang lebih besar, sehingga lebih sulit untuk mengendap. Nilai kekeruhan yang diperoleh adalah 23 NTU.

b. Pada kondisi $\mathrm{pH} 6,5$, proses yang terjadi hampir sama dengan yang terjadi pada $\mathrm{pH}$ 6,0 , namun ukuran flok agak sedikit lebih besar. Karena penggumpalan antara flok juga tidak terjadi, maka proses pengendapannya juga terjadi agak lama. Baik pada $\mathrm{pH}$ 6,0 maupun $\mathrm{pH}$ 6,5 hasil akhir dari pengendapan menghasilkan perubahan warna air dari warna teh menjadi warna sedikit kekuningan. Namun warna air belum seluruhnya dapat dihilangkan, tetapi masih tampak sedikit kuning. Nilai kekeruhan yang diperoleh adalah 20 NTU. 
c. Pada kondisi $\mathrm{pH} 7,0$ proses pembentukan flok terjadi dengan lebih cepat dan demikian pula dengan proses penggumpalannya. Dalam waktu satu menit setelah pencampuran sempurna, segera terjadi penggumpalan sehingga ukuran gumpalan menjadi semakin besar. Secara visual mulai terlihat semakin banyak terbentuknya gumpalan-gumpalan yang berwarna coklat muda, dan tidak lama kemudian (kurang dari 15 menit) terjadi pengendapan sempurna. Nilai kekeruhan yang diperoleh adalah 11 NTU.

d. Pada $\mathrm{pH} 7,5$, proses pembentukan flok dan penggabungan flok-flok berlangsung lebih cepat dan penggumpalan lanjut juga terjadi dengan lebih cepat. Proses pembentukan flok dan penggabungan flok hanya berlangsung dalam waktu sekitar 2 menit. Proses pengendapan juga berlangsung dengan lebih cepat, karena gumpalan yang terjadi juga lebih besar dan berat. Nilai kekeruhan yang diperoleh adalah 4 NTU.

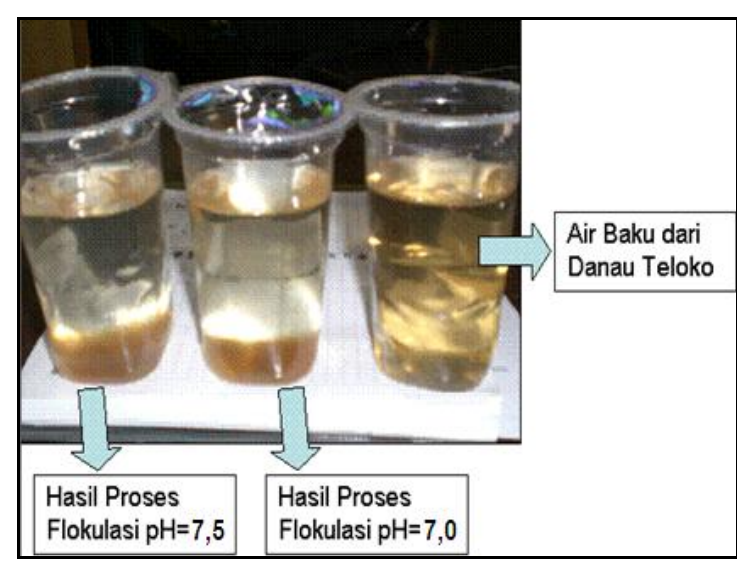

Gambar 5. Hasil Proses Flokulasi dan Sedimentasi Dari Air Baku Danau Teloko pada $\mathrm{pH} 7,0$ dan 7,5

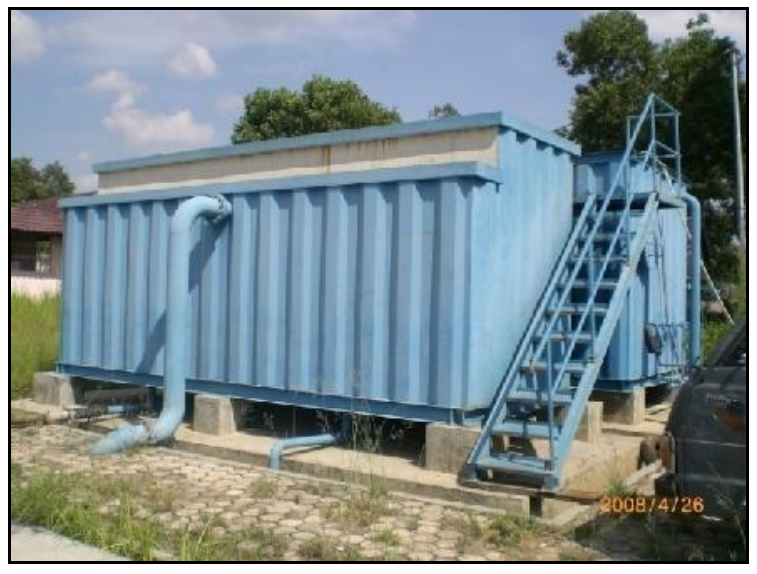

Gambar 6. IPA PDAM Teluk Gelam

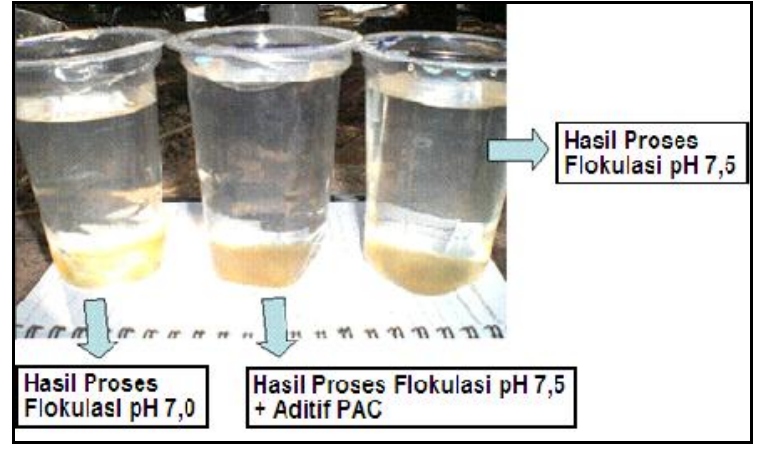

Gambar 7. Perbandingan Hasil Flokulasi dari Air Baku Teluk Gelam Ph 7,0 , 7,5 dan Penambahan Aditif PAC

\subsection{Optimasi Proses Koagulasi Flokulasi}

Untuk mengetahui kondisi optimal dari suatu proses harus dilakukan beberapa pengujian terhadap variabel-variabel yang berpengaruh. Variabel utama yang berpengaruh adalah suasana keasaman. Variabel lain yang juga mempunyai pengaruh berarti yaitu temperatur, jenis dan konsentrasi koagulan, jenis bahan pengotor dan kecepatan pengadukan dalam proses pencampuran. $\mathrm{Di}$ dalam menentukan kondisi optimal terhadap semua 6 variabel yang berpengaruh dibutuhkan pengujian secara lebih rinci dan harus dilaksanakan secara bertahap. Dalam uji coba ini hanya dilakukan optimasi derajat keasaman dan konsentrasi dosis senyawa penggumpal (koagulan) yang dalam hal ini adalah tawas.

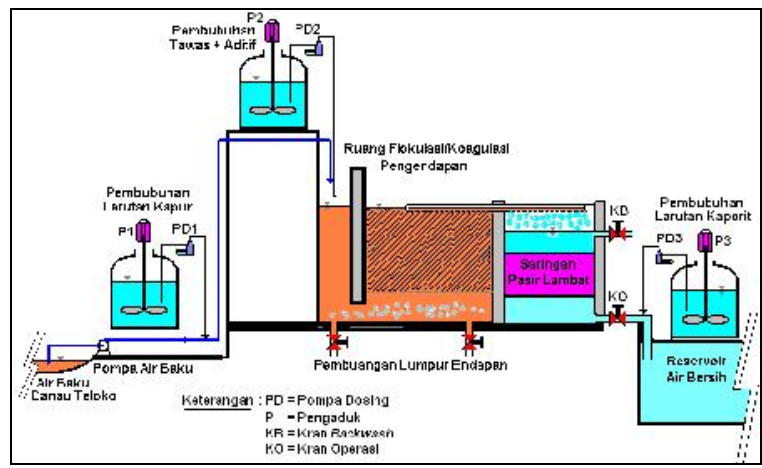

Gambar 8. Ilustrasi Proses Pengolahan Air Di PDAM Danau Teloko, Kabupaten OKI

Uji coba dengan peralatan Jar Test dilakukan lagi, tetapi keempat gelas kimia dibuat mempunyai derajat keasaman yang sama, yaitu $\mathrm{pH}=7,5$. Kemudian pada setiap gelas kimia yang sudah berisi air baku tersebut dibubuhkan dengan larutan tawas secara berurutan, sehingga konsentrasinya dalam gelas kimia masing-masing sebesar yaitu $\mathrm{C}_{1}=60 \mathrm{ppm}, \mathrm{C}_{2}=$ $70 \mathrm{ppm}, \mathrm{C}_{3}=80 \mathrm{ppm}$ dan $\mathrm{C}_{4}=90 \mathrm{ppm}$. Setelah pengadukan dan proses penggumpalan terjadi 
diperoleh hasil bahwa gelas kimia ke 3 merupakan hasil yang paling bagus. Jadi kondisi optimal dicapai pada $\mathrm{pH}=7,5$ dan jumlah tawas atau alum yang ditambahkan adalah sebesar 80 ppm. Sebagai pengujian tambahan telah pula dilakukan pembubuhan bahan kimia polimer sintetis PAC sebanyak $2 \mathrm{ml}$ dalam 1 liter air uji dan ternyata hasilnya dapat lebih baik, yaitu proses penggumpalan berlangsung dengan lebih cepat dan demikian pula proses pengendapannya.

\subsection{Jumlah Bahan Kimia Yang Dibutuhkan}

\begin{tabular}{|c|c|}
\hline $\begin{array}{l}\text { Berdasarkan } \\
\text { ampiran), } \quad \text { untuk } \\
\text { engolahan di PDAM }\end{array}$ & $\begin{array}{c}\text { perhitungan } \\
\text { melaksanakan proses } \\
\text { Danau Teloko dibutuhkan }\end{array}$ \\
\hline $\begin{array}{l}\text { Tawas sebanyak } \\
\text { rapasitas produksi } \\
\text { ter/detik. }\end{array}$ & $\begin{array}{l}138,24 \mathrm{~kg} / \mathrm{hari} \text { dengan } \\
\text { air minum sebesar } 40\end{array}$ \\
\hline
\end{tabular}

\section{KESIMPULAN DAN SARAN}

\subsection{Kesimpulan}

Dari hasil uji coba koagulasi-flokulasi yang telah dilakukan terhadap air baku bergambut yang berasal dari Danau Teloko dan Teluk Gelam dapat diambil kesimpulan sebagai berikut :

1. Sumber air Danau Teloko dan Teluk Gelam merupakan air gambut dengan nilai rata-rata $\mathrm{pH} 4$, sehingga untuk mengolahnya perlu adanya pengaturan nilai $\mathrm{pH}$ sebelum dilakukan proses koagulasi-flokulasi.

2. Secara umum unit-unit proses yang digunakan oleh PDAM Danau Teloko dan Teluk Gelam sudah cukup memadai, namun pengoperasian unit pemroses flokulasikoagulasi ternyata masih belum optimal.

3. Nilai $\mathrm{pH}$ yang optimum untuk proses Koagulasi-flokulasi dengan koagulan tawas yaitu $\mathrm{pH}$ 7,5 dan nilai kekeruhan yang dihasilkan adalah 4NTU.

4. Dosis optimum larutan tawas untuk proses koagulasi-flokulasi diperoleh 80 - 100 ppm.

5. Setelah proses koagulasi-flokulasi terjadi penurunan $\mathrm{pH}$ menjadi 4, sehingga perlu dilakukan proses pengaturan kembali menjadi $\mathrm{pH}=7$.

6. Untuk mengoperasikan proses pengolahan PDAM Danau Teloko dibutuhkan bahan koagulan Tawas sebanyak 138,24kg per hari.

\subsection{Saran}

Berdasarkan proses yang telah dilakukan di IPA Danau Teloko dan IPA Teluk
Gelam, maka dapat diungkapkan beberapa saran sebagai dasar perbaikan proses.

1. Proses pengaturan $\mathrm{pH}$ (pembubuhan larutan Kapur) dilakukan terpisah dengan proses Koagulasi-flokulasi (pembubuhanTawas).

2. Untuk mengetahui nilai $\mathrm{pH}$ secara akurat, maka perlu ada alat kontrol $\mathrm{pH}$.

3. Untuk mengatur besar dan kecilnya bahan kimia yang diinjeksikan, baik untuk pengaturan $\mathrm{pH}$, Koagulasi-flokulasi dan disinfeksi, maka perlu ada pompa dossing.

4. Untuk skala besar, tangki bahan kimia (larutan Tawas atau Kapur) perlu dilengkapi dengan sistem pengadukan. Hal ini dimaksudkan agar dalam tangki bahan kimia tidak terjadi pengendapan yang memungkinkan timbulnya ketidakhomogenan konsentrasi larutan bahan kimia tersebut.

5. Untuk menjamin terciptanya kondisi yang homogen setelah pembubuhan bahan kimia dibutuhkan sistem pencampuran yang sempurna. Cara pencampuran yang sementara ini digunakan oleh sistem IPA di Danau Teloko dan Teluk Gelam masih kurang sempurna, sehingga sistem pencampurannya perlu dimodifikasi.

6. Bila musim kemarau, dimana kualitas air baku memburuk (karena warna gambut menjadi lebih pekat), maka dibutuhkan bahan aditif dalam proses koagulasiflokulasi. Bahan aditif yang digunakan, misalnya PAC atau Siroflok. PAC adalah bahan kimia polimer sintetis dan berdasarkan literatur memang dapat membantu mempercepat terjadinya penggumpalan (4).

\section{DAFTAR PUSTAKA}

1. NN, "Pembangunan Sarana - Prasarana Fisik Dinas Pekerjaan Umum, Kabupaten Ogan Komering Ilir Tahun 2006", Dinas Pekerjaan Umum, Kabupaten OKI, Propinsi Sumatera Selatan, 2006.

2. NN, "Laporan Operasional PDAM Danau Teloko", Dinas Pekerjaan Umum, Kabupaten OKI, Propinsi Sumatera Selatan, 2007.

3. NN, "Laporan Operasional PDAM Teluk Gelam", Dinas Pekerjaan Umum, Kabupaten OKI, Propinsi Sumatera Selatan, 2007.

4. Peavy H. S., Rowe D. S., Tchobanoglous G., "Environmental Engineering", International Edition, McGraw-Hill, New York, 1986. 


\section{LAMPIRAN}

1. Perhitungan Kebutuhan Tawas/Alum :

Dari hasil jar test yang dilakukan, misalkan didapatkan dosis optimum tawas adalah $80 \mathrm{ppm}$. Maka perhitungan kebutuhan alum adalah sebagai berikut :

Kapasitas Produksi IPA Danau Teloko $=40$ It/det.

- Jika operasional $=12$ jam/hari

- Produksi air bersih:

$=40 \mathrm{lt} / \mathrm{det} \times 3600 \mathrm{det} / \mathrm{jam} \times 12 \mathrm{jam} / \mathrm{hari}$

$=1.728 .000 \mathrm{It} /$ hari $=1.728 \mathrm{~m}^{3}$.

- Kebutuhan alum/hari:

$=80 \mathrm{mg} / \mathrm{lt} \times 1.728 .000 \mathrm{lt} / \mathrm{hari}=138.240 .000$

$\mathrm{mg} / \mathrm{hari}=138,24 \mathrm{~kg} / \mathrm{hari}$

\section{Menyiapkan Pompa dosing Tawas/ PAC/Kaporit}

Pompa dosing (tawas, PAC, kaporit) sebelum dioperasikan harus disetel terlebih dahulu stroke pompa atau prosentase bukaan pompa, sehingga bahan kimia yang diinjeksikan akan sesuai dengan yang diinginkan.

\section{Pompa Dosing Tawas}

Debit injeksi tawas tiap jamnya perlu diketahui untuk menghitung berapa bukaan/ stroke pompa dosing yang akan dioperasikan.

Diketahui :

Larutan tawas dlm tangki $=20 \%=200 \mathrm{gr} / \mathrm{tt}=$ $200.000 \mathrm{mg} / \mathrm{lt}=\mathrm{C}_{1}$;

Debit pompa dosing $=Q_{1}$

Dosis optimum tawas $=80 \mathrm{mg} / \mathrm{lt}=\mathrm{C}_{2}$;

Debit air baku $=40 \mathrm{lt} / \mathrm{dt}=\mathrm{Q}_{2}$;

Debit pompa dosing adalah:

$\mathrm{Q}_{1}=\underline{\mathrm{Q}}_{2} \times \frac{\times \mathrm{C}_{2}}{\mathrm{C}_{1}}=\frac{40 \mathrm{lt} / \mathrm{dt} \times 80 \mathrm{mg} / \mathrm{lt}}{200.000 \mathrm{mg} / \mathrm{lt}}=0,016 \mathrm{lt} / \mathrm{dt}$

$\mathrm{Q}_{1}=57,6 \mathrm{lt} / \mathrm{jam}$.

Diketahui bahwa kapasitas pompa dosing maksimum, misalkan 100 It/jam,

maka pengaturan stroke pompa dosing adalah:

$$
\frac{57,6}{100} \times 100 \%=57,6 \%
$$

$\rightarrow$ setel stroke pompa dosing tawas pada angka $60 \%$. 